\title{
Common mental disorders in nursing technicians of a university hospital
}

\author{
Transtornos mentais comuns em técnicos de Enfermagem de um hospital universitário \\ Trastornos mentales comunes en técnicos de enfermería en un hospital universitario
}

Fabrício Ferreira dos Santos'
ORCID: 0000-0002-8212-8416
Maria Fernanda Santos Figueiredo Brito'
ORCID: 0000-0001-5395-9491
Lucinéia de Pinho'
ORCID: 0000-0002-2947-5806
Franciele Ornelas Cunha'
ORCID: 0000-0003-3038-6760
João Felício Rodrigues Neto'
ORCID: 0000-0002-6496-0460
Adélia Dayane Guimarães Fonseca"
ORCID: 0000-0002-1168-7106
Carla Silvana de Oliveira e Silva'
ORCID: 0000-0002-2752-1557

'Universidade Estadual de Montes Claros. Montes Claros, Minas Gerais, Brazil.

"Universidade Federal de Juiz de Fora. Montes Claros, Minas Gerais, Brazil.

How to cite this article: Santos FF, Brito MFSF, Pinho L, Cunha FO, Rodrigues-Neto JF, Fonseca ADG, et al. Common mental disorders in nursing technicians of a university hospital.

Rev Bras Enferm. 2020;73(1):e20180513. doi: http://dx.doi.org/10.1590/0034-7167-2018-0513

Corresponding Author:

Carla Silvana de Oliveira e Silva E-mail:profcarlasosilva@gmail.com

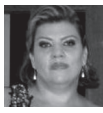

EDITOR IN CHIEF: Antonio José de Almeida Filho ASSOCIATE EDITOR: Elucir Gir

Submission: 06-12-2018

Approval: 09-04-2018

\section{ABSTRACT}

Objective: To verify the prevalence of common mental disorders and associated factors in nursing technicians. Method: Cross-sectional analytical study conducted at a university hospital. A questionnaire with sociodemographic, educational and work-related variables and the Self Reporting Questionnaire-20 were used to verify the presence of common mental disorders. Association analysis was performed using the chi-squared test, with a significance level of $5 \%$. Results: 280 nursing technicians participated in the study. The prevalence of common mental disorders was $46.9 \%$. The variables family income $(p=0.021)$ and working exclusively in health area $(p<0.001)$ were associated with the outcome. There was a higher prevalence of $C M D$ among individuals with a family income below four minimum wages ( $P R=1.41)$ and among professionals who worked exclusively in the health area $(P R=1.95)$. Conclusion: Approximately half of the nursing technicians of the university hospital presented common mental disorders, which were associated with economic and work-related variables.

Descriptors: Mental Disorders; Mental health; Occupational Health; Nursing Human Resources; Hospitals, University

\section{RESUMO}

Objetivo: Verificar a prevalência de transtornos mentais comuns em técnicos de enfermagem e fatores associados. Método: Estudo transversal, analítico, realizado em um hospital universitário. Utilizaram-se um questionário composto por variáveis sociodemográficas, de formação e ocupacionais e o Self Reporting Questionnaire-20 para verificar a presença de transtornos mentais comuns. Realizou-se a análise de associação por meio do teste de qui-quadrado, com nível de significância de 5\%. Resultados: Participaram 280 técnicos de enfermagem. A prevalência de transtornos mentais comuns foi de $46,9 \%$. As variáveis renda familiar $(p=0,021)$ e trabalho exclusivo na área da saúde $(p<0,001)$ apresentaram-se associadas ao desfecho. Observou-se maior prevalência de TMC entre os indivíduos com renda familiar inferior a quatro salários mínimos $(\mathrm{RP}=1,41)$ e entre os profissionais que trabalhavam exclusivamente na área de saúde $(\mathrm{RP}=1,95)$. Conclusão: Aproximadamente metade dos técnicos de enfermagem de hospital universitário apresentou transtornos mentais comuns, que foram associados a aspectos econômico e ocupacional.

Descritores: Transtornos Mentais; Saúde Mental; Saúde do Trabalhador;Técnicos de Enfermagem; Hospitais Universitários.

\section{RESUMEN}

Objetivo: Comprobar la prevalencia de trastornos mentales comunes en técnicos de enfermería y los factores asociados. Método: Se trata de un estudio transversal, analítico, realizado en un hospital universitario. Se utilizó un cuestionario compuesto por variables sociodemográficas, de formación y ocupacionales y el Cuestionario de Autorreporte de Síntomas-20 para comprobar la presencia de trastornos mentales comunes. Se llevó a cabo el análisis de asociación mediante la prueba chi-cuadrado, con nivel de significación del 5\%. Resultados: Participaron 280 técnicos de enfermería. La prevalencia de trastornos mentales comunes alcanzó el $46,9 \%$. Las variables ingreso familiar $(p=0,021)$ y trabajo exclusivo en el área de la salud $(p<0,001)$ estaban asociadas al desenlace. Fue posible observar una mayor prevalencia de TMC entre los individuos con ingresos familiares inferiores a cuatro sueldos mínimos $(\mathrm{RP}=1,41)$ y entre los profesionales que trabajaban exclusivamente en el área de la salud $(\mathrm{RP}=1,95)$. Conclusión: Aproximadamente la mitad de los técnicos de enfermería del hospital universitario presentó trastornos mentales comunes, asociados a aspectos económico y ocupacional.

Descriptores: Trastornos Mentales; Salud Mental; Salud del Trabajador; Técnicos de Enfermería; Hospital Universitario. 


\section{INTRODUCTION}

Work is important for the survival and personal achievement of individuals. However, it can also affect the worker's lifestyle and even lead to health problems, such as mental illnesses ${ }^{(1-2)}$. Among these, Common Mental Disorders (CMD) stand out and represent a serious public health problem due to their high incidence ${ }^{(3)}$.

Work-related CMD have been addressed in several studies in recent years ${ }^{(4)}$, as they are the third most common cause of sick leave in Brazil, with an annual rate of $6.2 \%$ of workers ${ }^{(3)}$. This disorder frequently affects workers in various areas ${ }^{(1,5)}$, including professionals who provide health care ${ }^{(6-9)}$. Adversity in the workplace can contribute to mental illness ${ }^{(10)}$. Nursing technicians are at risk of developing CMDs due to the peculiarities of their work - direct contact with difficult-to-manage patients, high psychological demand, low autonomy at work, low salaries, long working hours, fear of making errors during care, precarious working conditions which can lead to work overload and chronic stress ${ }^{(11-13)}$.

The presence of CMD in nursing technicians can affect the quality of patient care and the relationships within the work team and with the family and the community, reduce job satisfaction, damage the health of the professional, increase absenteeism, and generate additional costs to the institutions ${ }^{(14-16)}$. Health care can have direct impact on professionals in this area, with repercussions on quality of life, organizational indicators, and care delivery ${ }^{(12,15)}$.

Therefore, it is essential to investigate the presence of common mental disorders among nursing technicians working in hospitals, as this is a professional category with a large representation in health care. Studies on this topic should be carried out in different settings, due to regional, social, economic and cultural diversity. This knowledge can support the implementation of measures to protect the mental health of workers and, consequently, improve the functioning of health care.

\section{OBJECTIVE}

To verify the prevalence of common mental disorders and associated factors among nursing technicians of a university hospital in Montes Claros - MG.

\section{METHOD}

\section{Ethical Aspects}

The ethical conduct of this study is in accordance with the norms established in Resolution No. 466/12 of the National Health Council on Research involving Human Beings. The project of this research was approved by the Research Ethics Committee (REC) of the State University of Montes Claros - Unimontes. The Research Support Office of the hospital authorized this study by signing the institutional consent form. The study participants signed the Informed Consent Form.

\section{Design, setting and study period}

This is a cross-sectional and analytical study conducted at a university hospital in Montes Claros, northern Minas Gerais.
The institution has 172 beds and a structure for urgent and emergency care, a maternity ward and hospitalization in various clinical and surgical areas, including mental health, semi-intensive and intensive adult care, neonatal and pediatric treatment. The hospital has a distinguished history in the path of public health in the northern region of the state and sets the benchmark for the training of human resources in health. This research was conducted in September and October 2015.

\section{Population, inclusion and exclusion criteria}

In the year of data collection, the hospital had 300 nursing technicians, which were invited to participate in the research and constituted the study sample. Inclusion criterion was working as a nursing technician. Professionals who were on leave or vacation were excluded.

\section{Study protocol}

Data was collected by previously trained nursing students. The instrument was a self-administered questionnaire with socio-demographic, educational and work-related variables. The Self Reporting Questionnaire (SRQ-20) was used to verify the presence of CMD. The SRQ is an instrument developed by the World Health Organization to identify possible cases of CMD. Originally, the questionnaire consisted of 30 questions, 20 related to psychosomatic symptoms, for identifying non-psychotic disorders, four for screening psychotic disorders, one asking about tonic-clonic seizures and five questions about disorders by the use of alcohol. Due to the low sensitivity of self-administered instruments for tracking psychosis and seizures, the questions related to these conditions have fallen into disuse. The SRQ-20 is the SRQ version for the identification of CMD; it contains 20 questions which have to be answered by yes or no. It was validated in Brazil by Mari and Willians ${ }^{(17)}$. The score is obtained by simply counting the affirmative answers and it can range from 0 (minimum probability of CMD) to 20 (maximum probability of CMD). In this study, the cutoff score $\geq 7$ was used to identify possible cases of $\mathrm{CMD}^{(17-18)}$. This score presents a sensitivity of $83 \%$ and a specificity of $80 \%$. It is worth noting that this is a screening instrument, and not a diagnosis.

\section{Analysis of results and statistics}

Data analysis was performed in the Statistical Package for Social Sciences for Windows (SPSS, version 20.0). Descriptive analysis was based on absolute and relative frequency. Bivariate analysis was performed to assess the association between the independent variables and CMD, through the chi-squared test. Independent variables associated with CMD with a significance level of less than $20 \%$ ( $p \leq 0.20)$ were included in the multiple analysis. Subsequently, a multiple analysis with Poisson regression with robust variance was conducted. In the final adjusted model, variables with a significance level of less than $5 \%(p \leq 0.05)$ were maintained. Adjusted prevalence ratios and their respective 95\% confidence intervals were estimated. 


\section{RESULTS}

A total of 280 nursing technicians participated in the study. The non-response rate was $6.6 \%$. The professionals were mostly female $(58.6 \%)$, married (62.5\%) and with family income between one and three minimum wages (68.2\%). The mean age was 38.5 years $( \pm$ 6.84). Regarding training and professional data, most of the participants had completed high school (60.4\%), had no otheremployment (60.4\%) and worked exclusively in health (67.1\%). Nursing technicians had a mean time of work of 12.8 years (Table 1 ).

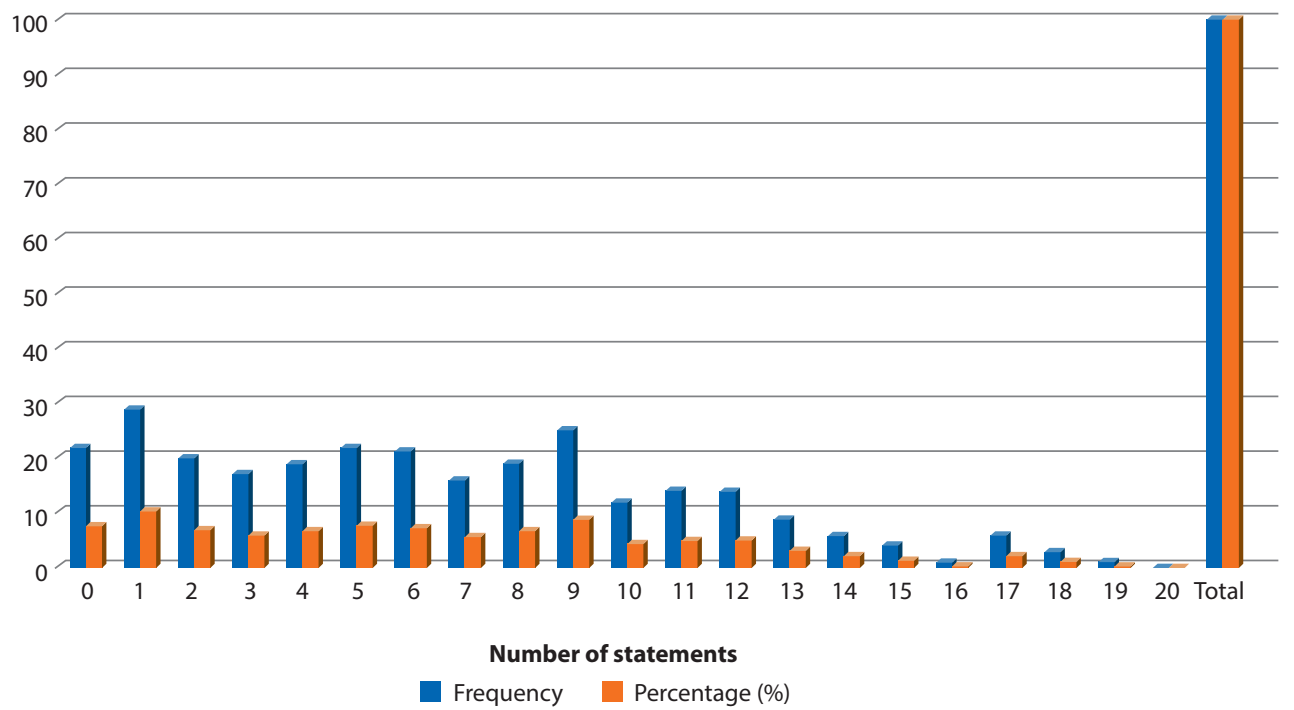

Figure 1 - Frequency of affirmative answers of nursing technicians from a university hospital using the SRQ-20, Montes Claros, Minas Gerais, Brazil, 2015 ( $N=280)$
Table 1 - Socio-demographic characteristics of nursing technicians of a university hospital, Montes Claros, Minas Gerais, Brazil, 2015 ( $\mathrm{N}=280)$

\begin{tabular}{|c|c|c|}
\hline Variables & $\mathbf{n}$ & $\%$ \\
\hline \multicolumn{3}{|l|}{ Gender } \\
\hline Male & 115 & 41.1 \\
\hline Female & 164 & 58.6 \\
\hline \multicolumn{3}{|l|}{ Civil status } \\
\hline Single & 68 & 24.3 \\
\hline Married & 175 & 62.5 \\
\hline Stable union & 4 & 1.4 \\
\hline Separated/divorced & 29 & 10.4 \\
\hline Widowed & 4 & 1.4 \\
\hline \multicolumn{3}{|l|}{ Skin color } \\
\hline White & & 40.0 \\
\hline Brown & 105 & 37.5 \\
\hline Black & 60 & 21.4 \\
\hline Yellow & 2 & 0.7 \\
\hline Missing & 1 & 0.4 \\
\hline \multicolumn{3}{|l|}{ Religion } \\
\hline Catholic & 179 & 63.9 \\
\hline Evangelical & 93 & 33.2 \\
\hline Spiritist & 2 & 0.7 \\
\hline Other & 1 & 0.4 \\
\hline No religion & 5 & 1.8 \\
\hline \multicolumn{3}{|l|}{ Family income } \\
\hline Less than 1 minimum wage & 3 & 1.1 \\
\hline 1 to 3 minimum wages & 191 & 68.2 \\
\hline 4 to 5 minimum wages & 80 & 28.6 \\
\hline More than 5 minimum wages & 6 & 2.1 \\
\hline \multicolumn{3}{|l|}{ Level of education } \\
\hline Complete elementary school & 1 & 0.4 \\
\hline Complete high school & 169 & 60.4 \\
\hline Incomplete higher education & 50 & 17.9 \\
\hline Complete higher education & 60 & 21.4 \\
\hline \multicolumn{3}{|l|}{ Other employment } \\
\hline Yes & 110 & 39.3 \\
\hline No & 169 & 60.4 \\
\hline Missing & 1 & 0.4 \\
\hline \multicolumn{3}{|l|}{ Working exclusively in health area } \\
\hline Yes & 188 & 67.1 \\
\hline No & 92 & 32.9 \\
\hline
\end{tabular}

Table 2 - Association analysis between Common Mental Disorders and independent variables among nursing technicians of a university hospital, Montes Claros, Minas Gerais, Brazil, 2015 ( $N=280)$

\begin{tabular}{|c|c|c|c|c|c|}
\hline Variables & \multicolumn{2}{|c|}{ Present } & \multicolumn{2}{|c|}{ Absent } & $p$ value \\
\hline \multicolumn{6}{|l|}{ Gender* } \\
\hline $\begin{array}{l}\text { Female } \\
\text { Male }\end{array}$ & $\begin{array}{l}80 \\
52\end{array}$ & $\begin{array}{l}60.6 \\
39.4\end{array}$ & $\begin{array}{l}84 \\
63\end{array}$ & $\begin{array}{l}56.8 \\
42.6\end{array}$ & 0.538 \\
\hline \multicolumn{6}{|l|}{ Age } \\
\hline $\begin{array}{l}\text { Less than } 40 \text { years } \\
\text { More than } 40 \text { years }\end{array}$ & $\begin{array}{l}95 \\
34\end{array}$ & $\begin{array}{l}73.6 \\
26.4\end{array}$ & $\begin{array}{c}100 \\
47\end{array}$ & $\begin{array}{l}68.0 \\
32.0\end{array}$ & 0.307 \\
\hline \multicolumn{6}{|l|}{ Civil status } \\
\hline $\begin{array}{l}\text { No partner } \\
\text { With partner }\end{array}$ & $\begin{array}{l}52 \\
80\end{array}$ & $\begin{array}{l}39.4 \\
60.6\end{array}$ & $\begin{array}{l}49 \\
99\end{array}$ & $\begin{array}{l}33.1 \\
66.9\end{array}$ & 0.274 \\
\hline \multicolumn{6}{|l|}{ Color } \\
\hline $\begin{array}{l}\text { White } \\
\text { Non-white }\end{array}$ & $\begin{array}{l}55 \\
76\end{array}$ & $\begin{array}{l}42.0 \\
58.0\end{array}$ & $\begin{array}{l}57 \\
91\end{array}$ & $\begin{array}{l}38.5 \\
61.5\end{array}$ & 0.555 \\
\hline \multicolumn{6}{|l|}{ Religion } \\
\hline $\begin{array}{l}\text { Has a religion } \\
\text { Doesn't have a religion }\end{array}$ & $\begin{array}{c}130 \\
2\end{array}$ & $\begin{array}{c}98.5 \\
1.5\end{array}$ & $\begin{array}{c}145 \\
3\end{array}$ & $\begin{array}{c}98.0 \\
2.0\end{array}$ & 0.747 \\
\hline \multicolumn{6}{|l|}{ Level of education } \\
\hline $\begin{array}{l}\text { More than eight years of education } \\
\text { Less than eight years of education }\end{array}$ & $\begin{array}{c}131 \\
1\end{array}$ & $\begin{array}{c}99.2 \\
0.8\end{array}$ & $\begin{array}{c}148 \\
0\end{array}$ & $\begin{array}{c}100.0 \\
0\end{array}$ & 0.289 \\
\hline \multicolumn{6}{|l|}{ Family income } \\
\hline $\begin{array}{l}\text { Four minimum wages or more } \\
\text { Less than four minimum wages }\end{array}$ & $\begin{array}{l}33 \\
99\end{array}$ & $\begin{array}{l}25.0 \\
75.0\end{array}$ & $\begin{array}{l}53 \\
95\end{array}$ & $\begin{array}{l}35.8 \\
64.2\end{array}$ & 0.050 \\
\hline $\begin{array}{l}\text { Time of work } \\
\text { Up to } 10 \text { years } \\
\text { More than } 10 \text { years }\end{array}$ & $\begin{array}{l}73 \\
73 \\
59\end{array}$ & $\begin{array}{l}55.3 \\
55.3 \\
44.7\end{array}$ & $\begin{array}{l}78 \\
78 \\
70\end{array}$ & $\begin{array}{l}52.7 \\
52.7 \\
47.3\end{array}$ & 0.663 \\
\hline \multicolumn{6}{|l|}{ Working exclusively in health area } \\
\hline $\begin{array}{l}\text { Yes } \\
\text { No }\end{array}$ & $\begin{array}{c}103 \\
29\end{array}$ & $\begin{array}{l}78.0 \\
22.0\end{array}$ & $\begin{array}{l}85 \\
63\end{array}$ & $\begin{array}{l}57.4 \\
42.6\end{array}$ & $<0.001$ \\
\hline
\end{tabular}

Note: *missing.

The prevalence of possible cases of CMD among the nursing technicians was $46.9 \%$. Figure 1 shows the frequency of affirmative answers of the professionals in the SRQ-20. It was observed that $7.5 \%$ of the participants had 6 affirmative answers, $5.7 \%$ had seven and $40.7 \%$ had more than seven. 
Regarding socio-demographic, educational and work-related variables, the bivariate analysis showed association between CMD and the following variables: family income $(p=0,05)$ and working exclusively in health $(p<0.001)$. The multiple analysis showed a higher prevalence of CMD among individuals with family income of less than four minimum wages $(P R=1.41)$ and those working exclusively in health $(P R=1.95)$.

Table 3 - Results of the multiple analysis association between Common Mental Disorders and the investigated variables among nursing technicians, Montes Claros, Minas Gerais, Brazil, 2015

\begin{tabular}{|c|c|c|c|}
\hline Independent Variables & PR & $95 \% \mathrm{Cl}$ & $p$ value \\
\hline \multicolumn{4}{|l|}{ Family income } \\
\hline Four minimum wages or more & 1 & & \\
\hline Less than four minimum wages & 1,41 & $1,05-1,89$ & 0,021 \\
\hline \multicolumn{4}{|l|}{ Working exclusively in health } \\
\hline No & 1 & & \\
\hline Yes & 1,95 & $1,39-2,73$ & $<0,001$ \\
\hline
\end{tabular}

\section{DISCUSSION}

This study found CMD in approximately half of the nursing technicians of a university hospital in Montes Claros - MG. The association between work and illness due to mental disorders has been observed in national ${ }^{(11,19)}$ and international studies ${ }^{(20)}$. Nursing professionals are at risk of developing these disorders, since they constantly experience situations of suffering, stress and anxiety ${ }^{(11,15)}$.

Health workers are exposed to stressful situations in their daily practice, such as direct contact with illness, pain and suffering of patients and their families, excessive responsibility, non-harmonious interpersonal and hierarchical relationships, very long working hours, strenuous work, low salaries, night shifts, lack of material, among others ${ }^{(2,7,11,18,21-22)}$.

This study found a higher prevalence of CMD than a study with nursing workers of a public hospital in Bahia ${ }^{(11)}$. Previous studies with healthcare workers in primary care also found lower rates of $C M D^{(2,7,13)}$. The psychosocial aspects of the work of these professionals make them vulnerable to CMD and may lead to absenteeism, longer sick-leaves and social security benefits ${ }^{(3,13,23)}$. This situation may have negative impacts on institutions and on society. Mental disorders can affect the workers' general health status and the quality of the care provided by these professionals ${ }^{(23-24)}$.

It was observed that $7.5 \%$ of participants were on the alert for CMD, as they had six positive answers. These findings are a warning for the percentage of professionals on the edge of mental disorders. Thus, because they are subject to daily stress, emotional demands and physical and psychological risks ${ }^{(24)}$, measures to protect mental health must be quickly implemented ${ }^{(25)}$.

Family income was significantly associated with $C M D$, with a higher prevalence of $C M D$ among individuals with family income of less than four minimum wages. In Brazil, healthcare technicians have lower wages, which can lead to demotivation ${ }^{(25)}$.

This association was also observed in a study conducted with community health workers from the Family Health Strategy teams in
Montes Claros - MG ${ }^{(6)}$. Income is a factor that can affect the mental health of professionals, causing stress and insecurity, since, when living with a low salary, the individual is deprived of participating in activities that require financial resources, such as leisure activities, or is required to have more than one job, resulting in emotional distress, mental disorders and illness, all with the expectation that a higher income would provide better living conditions $\mathbf{s}^{(21,26)}$.

For many professionals, the choice for a technical vocational education was due to their financial conditions at the time. In the national scenario, professional and vocational education courses are options to access a better life. However, many nursing technicians want to change career and find a better paying and socially valued work, with the objective of improving their living conditions ${ }^{(25,27)}$. Thus, the idealization of the profession conflicts with the reality, which is often very distant from their dream work. They stay in the profession because they need the work to support themselves ${ }^{(27)}$. This situation can generate dissatisfaction, frustration and demotivation.

The search for increased income by technicians may occur by taking on other paid activities in parallel with their employment contract, in the health sector or outside it ${ }^{(25)}$.

Working exclusively in health area was statistically associated with CMD. Healthcare jobs require different work dynamics, greater attention, joint and coordinated work, constant and close contact with patients with serious diseases and with death, and involve a strong emotional demand ${ }^{(7,15)}$. The work of the nursing technician in the hospital involves a high number of procedures, a lot of contact with patients, low salaries and long standing periods, which can be stressors for these workers ${ }^{(21-22)}$. In addition, this professional category constantly deals with hierarchy of functions and knowledge, which can generate conflicts and paradoxes in work relations. Process control is limited because they perform actions arranged by other health professionals and do not directly participate in decisions related to their work, which affects their autonomy within the work process and interferes with the construction of knowledge ${ }^{(27)}$.

\section{Study limitations}

This study should be interpreted considering the limitations of the cross-sectional design and of the hospital scenario, which preclude the cause and effect relationship and the generalization of results, respectively. The exclusion of professionals who were on leave or vacation may have underestimated the prevalence of CMD in this study.

\section{Contributions to the areas of nursing, health or public policies}

The nursing professional, actor of care, is essential for a comprehensive care to individuals in hospitals. Their job is to provide quality of care, which, in turn, depends on their health condition. In the face of the high prevalence of CMD among nursing technicians found in this study, health managers must develop actions aimed at protecting and promoting mental health. Workers' health policies should consider the peculiarities of the work of the nursing technician. 
Regular clinical supervisions are an important tool, as they can provide professional support in order to reduce stress, increase satisfaction and preserve the emotional and mental integrity of health workers. Organizations should be aware of the need to provide regular clinical supervision and workers should not neglect them ${ }^{(28)}$. It is essential to establish measures that value the work of technicians, with career plans and better salaries.

\section{CONCLUSION}

In this study, the high prevalence of CMD among nursing technicians of a university hospital was verified and statistically associated with family income and working exclusively in health area. Further studies to investigate other aspects of the nursing technician's mental health should be conducted.

\section{REFERENCES}

1. Oliveira GB, Boery EN, Santos VC, Anjos KF, Boery RNSO. Mental health, work and lifestyle associated with the quality of life of workers. Rev Enferm UFPE. 2017;11(2):559-66. doi: 10.5205/reuol.10263-91568-1-RV.1102201710

2. Araújo TM, Mattos AIS, Almeida MMG, Santos KOB. Psychosocial aspects of work and common mental disorders among health workers: contributions of combined models. Rev Bras Epidemiol. 2016;19(3):645-57. doi: 10.1590/1980-5497201600030014

3. Silva Junior JS, Fischer FM. Disability due to mental illness: social security benefits in Brazil 2008-2011. Rev Saúde Pública. 2014;48(1):186-90. doi: 10.1590/S0034-8910.2014048004802

4. Silva SM, Baptista PCP, Felli VEA, Martins AC, Sarquis LMM, Mininel VA. Intervention strategies for the health of university hospital nursing staff in Brazil. Rev Latino-Am Enfermagem. 2013;21(1):[09 telas]. doi: 10.1590/S0104-11692013000100003

5. Ferreira RC, Silveira AP, Sá MAB, Feres SBL, Souza JGS, Martins AMEBL. Transtorno mental e estressores no trabalho entre professores universitários da área da saúde. Trab Educ Saúde. 2015;13(1):135-55. doi: 10.1590/1981-7746-sip00042

6. Santos AMVS, Lima CA, Messias RB, Costa FM, Brito MFSF. Transtornos mentais comuns: prevalência e fatores associados entre agentes comunitários de saúde. Cad Saúde Colet. 2017;25(2):160-8. doi: 10.1590/1414-462×201700020031

7. Carvalho DB, Araújo TM, Bernardes KO. Transtornos mentais comuns em trabalhadores da Atenção Básica à Saúde. Rev Bras Saude Ocup. 2016;41:e17. doi: 10.1590/2317-6369000115915

8. Alves AP, Pedrosa LAK, Coimbra MAR, Miranzi MAS, Haas VJ. Prevalence of common mental disorders among health professionals. Rev Enferm UERJ. 2015;23(1):64-9. doi: 10.12957/reuerj.2015.8150

9. Knuth BS, Silva RA, Oses JP, Radtke VA, Cocco RA, Jansen K. Mental disorders among health workers in Brazil. Ciênc Saúde Colet. 2015;20(8):2481-8. doi: 10.1590/1413-81232015208.05062014

10. Guimarães ALO, Felli VEA. Notification of health problems among nursing workers in university hospitals. Rev Bras Enferm. 2016;69(3):47582. doi: 10.1590/0034-7167.2016690313i

11. Rodrigues EP, Rodrigues US, Oliveira LMM, Laudano RCS, Nascimento Sobrinho CL. Prevalência de transtornos mentais comuns em trabalhadores de enfermagem em um hospital da Bahia. Rev Bras Enferm. 2014;67(2):296-301. doi: 10.5935/0034-7167.20140040

12. Ansoleaga E. Indicadores de salud mental asociados a riesgo psicosocial laboral en un hospital público. Rev Med Chile. 2015;143(1):47-55. doi: 10.4067/S0034-98872015000100006

13. Mattos AIS, Araújo TM, Almeida MMG. Interaction between demand-control and social support in the occurrence of common mental disorders. Rev Saúde Pública. 2017;51:48. doi: 10.1590/s1518-8787.2017051006446

14. Souza MNM, Martins Jr DF, Silva MV, Costa JA, Nascimento Sobrinho CL. Trabalho e saúde dos profissionais de enfermagem de um hospital especializado de Feira de Santana, Bahia. Rev Baiana Saúde Pública. 2011;35(Supl 1):38-54. doi: 10.22278/2318-2660.2011.v35.n0.a146

15. Santana LL, Sarquis LMM, Brey C, Miranda FMA, Felli VEA. Absenteeism due to mental disorders in health professionals at a hospital in southern Brazil. Rev Gaúcha Enferm. 2016;37(1):e53485. doi: 10.1590/1983-1447.2016.01.53485

16. Scherer MDA, Oliveira NA, Pires DEP, Trindade LL, Gonçalves ASR, Vieira M. Aumento das cargas de trabalho em técnicos de enfermagem na atenção primária à saúde no Brasil. Trab Educ Saúde 2016;14(Supl 1):89-104. doi: 10.1590/1981-7746-sol00030.

17. Mari JJ, Willians P. A validity study of a psychiatric screening questionnaire (SRQ-20) in primary care in the city of São Paulo. Br J Psychiatry. 1986;148:23-6. doi: 10.1192/bjp.148.1.23

18. Ferreira NN, Lucca SR. Burnout syndrome in nursing assistants of a public hospital in the state of São Paulo. Rev Bras Epidemiol. 2015;18(1):68-79. doi: 10.1590/1980-5497201500010006

19. Tavares JP, Magnago TSBS, Beck CLC, Silva RM, Prestes FC, Lautert L. Prevalence of minor psychiatric disorders in nursing professor. Esc Anna Nery. 2014;18(3):407-14. doi: 10.5935/1414-8145.20140058

20. Yamauchi T, Yoshikawa T, Sasaki T, Matsumoto S, Takahashi M, Suka M, et al. Cerebrovascular/cardiovascular diseases and mental disorders due to overwork and work-related stress among local public employees in Japan. Ind Health. 2018;56(1):85-91. doi: 10.2486/ indhealth.2017-0131

21. Instituto de Pesquisa Econômica Aplicada (IPEA). Radar: Tecnologia, produção e comercio exterior. Diretoria de Estudos e Politicas Setoriais, de Inovação, Regulação e Infraestrutura [Internet]. Brasília: IPEA; 2013 [cited 2018 Mar 21]. Available from: http://www.ipea.gov.br/portal/ 
Common mental disorders in nursing technicians of a university hospital Santos FF, Brito MFSF, Pinho L, Cunha FO, Rodrigues-Neto JF, Fonseca ADG, et al.

images/stories/PDFs/radar/150917_radar_40.pdf

22. Waters TR, Dick RB. Evidence of health risks associated with prolonged standing at work and intervention effectiveness. Rehabil Nurs. 2015;40(3):148-65. doi: 10.1002/rnj.166

23. Oliveira LA, Baldaçara LR, Maia MZB. Afastamentos por transtornos mentais entre servidores públicos federais no Tocantins. Rev Bras Saúde Ocup. 2015;40(132):156-69. doi: 10.1590/0303-7657000092614

24. Magnago TSBS, Prochnow A, Urbanetto JS, Greco PBT, Beltrame M, Luz EMF. Relationship between work ability in nursing and minor psychological disorders. Texto Contexto Enferm. 2015;24(2):362-70. doi: 10.1590/0104-07072015002580013

25. Vieira M, Chinelli F, d'Ávila LS, Fortes DR, David NAS. Trajetórias educacionais e ocupacionais de trabalhadores do Sistema Único de Saúde, e suas expectativas profissionais. Saúde Debate. 2017;41(spe2):92-103. doi: 10.1590/0103-11042017s208

26. Vieira TG, Beck CLC, Dissen CM, Camponogara S, Gobatto M, Coelho APF. Adoecimento e uso de medicamentos psicoativos entre trabalhadores de enfermagem de unidades de terapia intensiva. Rev Enferm UFSM. 2013;3(2):205-14. doi: 10.5902/217976927538

27. Fischborn AF, Viegas MF. A atividade dos trabalhadores de enfermagem numa unidade hospitalar: entre normas e renormalizações. Trab Educ Saúde. 2015;13(3):657-74. doi: 10.1590/1981-7746-sip00060

28. McCarron RH, Eade J, Delmage E. The experience of clinical supervision for nurses and healthcare assistants in a secure adolescent service: affecting service improvement. J Psychiatr Ment Health Nurs. 2018;25(3):145-56. doi: 10.1111/jpm.12447 